\title{
Identification of genetic markers of resistance to Artemisinin Combination Therapy in the rodent model Plasmodium chabaudi
}

\author{
Louise A Rodrigues ${ }^{1 *}$, Gisela Henriques ${ }^{1}$, Sofia T Borges ${ }^{1}$, Paul Hunt ${ }^{2}$, Cecília P Sanchez $^{3}$, Axel Martinelli ${ }^{1}$, \\ Pedro Cravo ${ }^{1}$ \\ From Parasite to Prevention: Advances in the understanding of malaria \\ Edinburgh, UK. 20-22 October 2010
}

\section{Background}

Effective treatment of malaria relies mostly on Artemisin Combination Therapy (ACT), which consists of the administration of an Artemisinin (ART) derivative in conjunction with a chemically unrelated anti-malarial, such as Mefloquine (MF). ACTs should reduce the chances of a parasite carrying mutations conferring resistance to both drugs [1]. However, parasites resistant to the different components of the combination have recently been reported. For instance, in Southeast Asia, the appearance of parasites showing increased in vivo tolerance to artesunate (ATN) [2,3] may undermine the future efficacy of the ATN+MF combination.

We have previously selected stable resistance to ATN in the rodent malaria parasite Plasmodium chabaudi [4]. ATN-resistant parasites showed a mutation on pcubp 1 gene, coding fora deubiquitinating enzyme [5]. No changes were found in thepcatp6 and and pcmdr1 genes [4].

In order to study the genetics of resistance to ACTs, the ATN-resistant P.chabaudi clone was repeatedly subinoculated into mice continuously treated with ATN + MF. Upon reaching a certain level of resistance, parasites were cloned by limiting dilution. The parasites' genetic background was investigated by SOLEXA whole genome re-sequencing. The identified mutations were confirmed by dideoxy sequencing real-time polymerase chain reaction.

\section{Results}

Selection and cloning procedures originated five parasite clones, of which only one, denoted AS-ATNMF-1, was investigated. When compared to the ATN-resistant progenitor, AS-ATNMF-1 is resistant to treatment with the combination of both ATN+MF, as well as to each drug separately.

AS-ATNMF-1 carries three distinctive mutations one of which is a duplication of the $m d r 1$ gene. The remaining two mutations are SNPs in genes of unknown function and remain to be further investigated. No differences were found in the coding sequences of pcatp 6 and pcubp 1 when comparing AS-ATNMF-1 and its progenitor.

\section{Conclusions}

This work provides strong evidence to support the possibility of the emergence of resistance to ACTs, even when the two drugs of the combination are administered simultaneously. Additionally, duplication of the $m d r 1$ gene may play a role in mediating ATN + MF resistance. However, the presence of other mutations seems to be required for the expression of this phenotype.

\footnotetext{
Author details

'Centro de Malária e Outras DoençasTropicais/IHMT/UNL, UEl Biologia Molecular, UEl Malária, Lisbon, Portugal. ${ }^{2}$ Centre for Immunity, Infection and Evolution, School of Biological Science, The University of Edinburgh, Edinburgh, UK. ${ }^{3}$ Hygiene Institut, Abteilung Parasitologie, Universita tsklinikum Heidelberg, Im Neuenheimer Feld 324, 69120 Heidelberg, Germany.
}

Published: 20 October 2010 


\section{References}

1. White $\mathrm{N}$ : Antimalarial drug resistance and combination chemotherapy. Philos Trans R Soc Lond B Biol Sci 1999, 354:739-49.

2. Carrara VI, Zwang J, Ashley EA, Price RN, Stepniewska K, Barends M, Brockman A, Anderson T, McGready R, Phaiphun L, Proux S, van Vugt M, Hutagalung R, Lwin KM, Phyo AP, Preechapornkul P, Imwong M, Pukrittayakamee S, Singhasivanon P, White NJ, Nosten F: Changes in the treatment responses to artesunate-mefloquine on the northwestern border of Thailand during 13 years of continuous deployment. PLOS One 2009, 4:e455.

3. Dondorp AM, Nosten F, Yi P, Das D, Phyo AP, Tarning J, Lwin KM, Ariey F, Hanpithakpong W, Lee SJ, Ringwald P, Silamut K, Imwong M, Chotivanich K, Lim P, Herdman T, An SS, Yeung S, Singhasivanon P, Day NP, Lindegardh N, Socheat $D$, White $N$ : Artemisinin resistance in Plasmodium falciparum malaria. N Engl J Med 2009, 361:455-67.

4. Afonso A, Hunt P, Cheesman S, Alves AC, Cunha CV, do Rosário V, Cravo P: Malaria parasites can develop stable resistance to artemisinin but lack mutations in candidate genes atp6 (encoding the sarcoplasmic and endoplasmic reticulum Ca2+ ATPase), tctp, mdr1, and cg10. Antimicrob Agents Chemother 2006, 50:480-9.

5. Hunt P, Afonso A, Creasey A, Culleton R, Sidhu AB, Logan J, Valderramos SG, McNae I, Cheesman S, do Rosario V, Carter R, Fidock DA, Cravo P: Gene encoding a deubiquitinating enzyme is mutated in artesunate- and chloroquine-resistant rodent malaria parasites. Mol Microbiol 2007, 65:27-40.

doi:10.1186/1475-2875-9-S2-026

Cite this article as: Rodrigues et al:: Identification of genetic markers of resistance to Artemisinin Combination Therapy in the rodent model Plasmodium chabaudi. Malaria Journal 2010 9(Suppl 2):O26.

\section{Submit your next manuscript to BioMed Central and take full advantage of:}

- Convenient online submission

- Thorough peer review

- No space constraints or color figure charges

- Immediate publication on acceptance

- Inclusion in PubMed, CAS, Scopus and Google Scholar

- Research which is freely available for redistribution

Submit your manuscript at www.biomedcentral.com/submit 